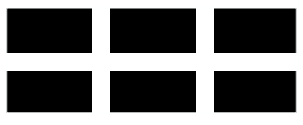

ThE William DAVIDSON INSTITUTE AT THE UNIVERSITY OF MICHIGAN BUSINESS SCHOOL

\title{
Testing for inflation convergence between the Euro Zone and its CEE partners
}

\author{
By: Imed Drine and Christophe Rault
}

William Davidson Institute Working Paper Number 768

April 2005 


\title{
Testing for inflation convergence between the Euro Zone and its CEE partners
}

\author{
Imed DRINE, \\ EUREQua, Sorbonne University ${ }^{1}$, \\ Christophe RAULT, \\ EPEE, University of Évry-Val d'Essonne and IZA ${ }^{2}$
}

April 6, 2005

\begin{abstract}
We investigate inflation convergence between the Euro Zone and its CEE partners using panel data methods that incorporate structural shifts. We find strong rejections of the unit root hypothesis, and therefore evidence of PPP, in the East-European countries for the 1995:1 to 2000:4 period.

Keywords: Purchasing power parity, inflation convergence, developing country, panel unit-root tests allowing structural breaks.

JEL Classification : E31, F0, F31, C15.
\end{abstract}

\footnotetext{
${ }^{1}$ Paris I, Maison des Sciences de l'Economie, 106-112 bd. de L'Hôpital, 75647 Paris Cedex 13, France. E-mail :drine@univ-paris1.fr

${ }^{2}$ University of Evry-Val d'Essonne, Département d'économie, Boulevard François Mitterrand, 91025 Évry Cedex, France. E-mail : chrault@hotmail.com, web-site : http://www.multimania.com/chrault/index.html
} 


\section{Introduction}

The East-European country efforts towards monetary and economic stabilization culminated with the integration to the European Union. As delineated by the Treaty of Maastricht, membership in the Euro required the achievement of five criteria, including inflation convergence and nominal exchange rate stability within its member states. In this effort of cohesion, Central and East European (CEE) countries had to achieve a nominal exchange rates and inflation convergence.

The Purchasing Power Parity (PPP) hypothesis considers a proportional relation between the nominal exchange rate and the relative price ratio, which implies that the real exchange rate is constant over time. So, one way to analyze price convergence between CEE countries European Union is to test if the PPP holds. The most common way to test for PPP consists in investigating unit roots in real exchange rates. If the unit root can be rejected in favor of level stationarity, then deviations from parity are temporary and PPP is said to hold in long run.

As it is now well-known, long-run PPP or mean reversion in real exchange rates is a standard but critical assumption of modern exchange rate theories. It is also of import to policy makers concerned by sizeable short run deviations from PPP in recent years. Given its importance in international finance, the long-run PPP relationship has been subjected to extensive empirical investigation during the last decade, both using conventional time series econometric techniques as well as recent panel data unit root tests (see Levin and Lin, 1993, 2002; Im, Pesaran and Shin, 1997, 2003, IPS hereafter); Maddala and Wu, 1999) and panel data cointegration tests (see Pedroni, 1999, 2000, 2004; McCoskey and Kao, 1998, Kao, 1999). However, the consensus amongst researchers seems to be mixed (see, for example, Sarno and Taylor, 2002; O’Connell, 1998; Frankel and Rose, 1996). Several reasons can account for these diverging results, including lack of power of unit root tests, appropriate price indices, the degree of cross correlation and heterogeneity of the series in the panel, structural breaks,.....).

This paper examines one possible explanation for these conflicting results, related to structural breaks, using real exchange rate annual data for 9 Central and East European countries (Croatia, the Czech Republic, Estonia, Hungary, Latvia, Lithuania, Poland, Slovakia and Slovenia), covering the period from the first quarter of 1995 to the last quarter of 2000. One 
important contribution of our paper is that we employ the recent unit panel data unit-root test based on the Lagrangian multiplier (LM) principle developed by Im and Lee (2001) which is very flexible since it can be applied when a structural break occurs at different time period in each time series as well as when the structural break occurs in only some of the time series. The proposed test not only is robust to the presence of structural breaks, but is more powerful than the popular IPS test in the basic case where no structural breaks are involved. The former property in particular bears very important implication for empirical work since no other test has been developed yet which can handle the presence of structural shifts in a practical way. Further, as reported by Im and Lee (2001), since the LM test loses little power by controlling for spurious structural breaks when

they do not exist, it is a reasonable strategy to control for breaks even when they are only at a suspicious level.

The remainder of the paper is organized as follows. In Section 2 we briefly discuss the PPP specification. In section 3 we present the panel data unit root test that will be used in the empirical application. In section 4 we expose and comment our econometric results for 9 nine Central and East European countries. A final section reviews the main findings. The central result of our paper is that there is a strong evidence of PPP for our 9 CEE countries.

\section{The PPP framework}

Strong PPP is usually expressed by a long-run relationship between the nominal exchange rate and the ratio of domestic to foreign price levels, i.e.

$$
s_{t}=\alpha+\beta\left(p_{t}-p_{t}^{*}\right)+u_{t}
$$

, where $s_{t}$ is the nominal exchange rate, and $p_{t}, p_{t}^{*}$ are, respectively domestic and foreign prices, all measured in logs. Equation (1) does impose an a-priori restriction on the cointegrating vector, i.e. the symmetry condition on the price coefficients. 
Another commonly used specification of PPP in unit root tests is given by

$$
q_{t}=s_{t}-p_{t}+p_{t}^{*}
$$

where $q_{t}$ is the real exchange rate.

The PPP equation (2) requires $\beta=1$. The presence of a unit root will imply that the PPP does not hold in the long run. Since all unit root tests on the real exchange rate assume implicitly that such restriction holds, a failure of these tests to find evidence favouring mean reversion in the real exchange rate may be caused by a failure of such a restriction. Various explanations have been offered for the potential rejection of this condition. Sarno and Taylor (2002) stress the importance of measurement errors, barriers to trade and other economically unimportant factors, while Froot and Rogoff (1995) suggest the possibility of a common trend in the relative prices of traded and non-traded goods. These explanations are however still the object of debate and besides it seems difficult to know if the rejection of strong PPP is not actually due to the low power of the conventional unit-root tests in small samples in the presence of structural breaks. The recent developments of panel data integration techniques allow us henceforth to bridge up this gap and to re-assess the validity of the PPP concept for CEE countries.

\section{Panel LM Unit Root Tests in the presence of a time break.}

Despite the fact that the testing methodologies employed in the more recent research offer distinct advantages, none of these tests combine panel data and structural breaks. In an effort to seek a more accurate investigation of the PPP, our paper extends the previous research by employing the panel LM unit root test developed by Im and Lee (2001). This test has the advantage of utilizing both panel data and structural breaks when testing for unit root. Unlike the IPS and other related panel unit root tests, the panel LM test can successfully take structural breaks into account without the necessity to simulating new critical values that depend on the number and location of breaks. 


\subsection{LM Test with no Structural Break}

To illustrate the underlaying model and testing procedure, we suppose that the data $y_{i t}, t=1,2, \ldots \ldots ., T ; i=1,2, \ldots \ldots . ., N$, is generated as :

$$
y_{i t}=x_{i t}+z_{i t}, \quad x_{i t}=\phi_{i} x_{i, t-1}+\varepsilon_{i t}, z_{i t}=\gamma_{1 i}+\gamma_{2 i} t
$$

The unit root test consists to test the null hypothesis of unit roots $\phi_{i}=1$ for all $i$. To do so, we express $y_{i t}$ as :

$$
\Delta y_{i t}=\beta_{i} y_{i, t-1}-\beta \gamma_{1 i}+\left[1-\beta_{i}(t-1)\right] \gamma_{2 i}+\varepsilon_{i t}, t=1,2, \ldots . T ; i=1,2, \ldots . . N,
$$

where $\beta_{i}=-\left(1-\phi_{i}\right)$. We then have the null hypothesis :

$H_{0}: \beta=0$ for all $i$,

against the alternatives :

$H_{1}: \beta_{i}<0, i=1,2, \ldots, N_{1}, \beta_{i}=0, i=N_{1}+1, N_{1}+2, \ldots ., N$

Therefore, all or some of the time series are stationary under the alternative hypothesis.

We suppose that the error terms $\varepsilon_{i t}, i=1,2, \ldots ., T$, are independent normal variables with mean zero and variance $\sigma_{i}^{2}$.

Let $L M_{i T}$ be the LM statistic for the i-th time series, then the LM statistic based on pooled likelihood function can be defined as :

$$
L M_{N T}=\sum_{i=1}^{N} L M_{i T}
$$


The distribution of $L M_{N T}$ depends on $\mathrm{N}$ and $\mathrm{T}$, but not on any other nuisance parameters under the null hypothesis. Therefore, $L M_{N T}$ itself may be used in practice as a statistic. However, as $\mathrm{N}$ increases, as long as the second moment of $L M_{i T}$ exists, the distribution of $L M_{N T}$ will approach a normal distribution. We denote the average of the individual LM statistic $L M_{i T}$ as :

$$
\overline{L M}_{N T}=\frac{1}{N} \sum_{i=1}^{N} L M_{i T},
$$

Let $E\left(\varepsilon_{T}\right)$ and $V\left(£_{T}\right)$ be the expected value and variance of $L M_{i T}$ under the null hypothesis. Then, under the null hypothesis,

$$
\Gamma_{L M}=\frac{\sqrt{N}\left[\overline{L M}_{N T}-E\left(£_{T}\right)\right]}{\sqrt{V\left(£_{T}\right)}} \Rightarrow N(0,1)
$$

as $\mathrm{N}$ grows (for finite $\mathrm{T}$ ), as long as $V\left(£_{T}\right)$ and $E\left(£_{T}\right)$ exist.

\subsection{Panel LM Test with Break}

In this section we define the LM panel unit root test in the presence of structural change. Suppose structural shift occurs at time period $T_{B, i}$ in i-th time series. Therefore, the data are generated as:

$$
\begin{aligned}
& y_{i t}=x_{i t}+z_{i t}, x_{i t}=\phi_{i} x_{i, t-1}+\varepsilon_{i t}, z_{i t}=\gamma_{1 i}+\gamma_{2 i} t+\delta_{i} D_{i t}, \\
& \text { for } t=0,1,2, \ldots \ldots, T ; i=1,2, \ldots ., N \text {, where } \\
& D_{i t}=\left\{\begin{array}{cc}
0 & t<T_{B, i} \\
0 & t>T_{B, i+1},
\end{array}\right\}
\end{aligned}
$$

which has an alternative representation: 


$$
\begin{aligned}
& \Delta y_{i t}=\beta_{i} y_{i, t-1}-\beta_{i} \gamma_{1 i}+\left[1-\beta_{i}(t-1)\right] \gamma_{2 i}+\left(\Delta D_{i t}-\beta_{i} D_{i t}\right) \delta_{i}+\varepsilon_{i t}, \\
& \text { for } t=1,2, \ldots, T ; i=1,2, \ldots, N \text {, where } \Delta D_{i t}=D_{i t}-D_{i, t-1, \text { i.e., }} \\
& \Delta D_{i t}=\left\{\begin{array}{cc}
1 & t=T_{B, i}+1 \\
0 & \text { otherwise }
\end{array}\right\}
\end{aligned}
$$

The LM statistic based on the pooled likelihood function is given by the sum of the LM statistics with break, $L M_{i T}^{B}$ so that $L M_{N T}^{B}=\sum_{i=1}^{N} L M_{i T}^{B}$.

Let

$$
\overline{L M}_{N T}^{B}=\frac{1}{N} \sum_{i=1}^{N} L M_{i T}^{B}
$$

As Amsler and Lee (1995) showed, the distribution of $L M_{i T}^{B}$ does not depend on the location of the break point $\lambda_{i}=\frac{T_{B, I}}{T}$ in the limit. In finite sample, however, the distribution of $L M_{i T}^{B}$ does depend on $\lambda_{i}$. If we have the exact expected value and the exact variance of $L M_{i T}^{B}$ under the null hypothesis, which we denote $E\left[\varepsilon_{T}^{B}\left(\lambda_{i}\right)\right]$ and $V\left[£_{T}^{B}\left(\lambda_{i}\right)\right]$, then it follows that

$$
\Gamma_{L M}^{B *}=\frac{\sqrt{N}\left[\overline{L M}_{b}-\frac{1}{N} \sum_{i=1}^{N} E\left[£_{T}^{B}\left(\lambda_{i}\right)\right]\right]}{\sqrt{\frac{1}{N} \sum_{i=1}^{N} V\left[£_{T}^{B}\left(\lambda_{i}\right)\right]}} \Rightarrow N(0,1)
$$

under the null hypothesis, as $\mathrm{N} \rightarrow \infty$, as long as $V\left[\varepsilon_{T}^{B}\left(\lambda_{i}\right)\right]$ exists of all $\mathrm{i}$.

However, the statistic $\Gamma_{L M}^{B^{*}}$, as it stands, is not very practical since it requires $E\left[{\varepsilon_{T}^{B}}^{B}\left(\lambda_{i}\right)\right]$ and $V\left[\varepsilon_{T}^{B}\left(\lambda_{i}\right)\right]$ for all $\lambda_{i}$ in the sample.

Since $L M_{i T}^{B}-L M_{i T}=o_{p}(1)$, we consider a practical statistic using $V\left(\varepsilon_{T}\right)$ and $E\left(\varepsilon_{T}\right)$ in 
place of $E\left[\varepsilon_{T}^{B}\left(\lambda_{i}\right)\right]$ and $V\left[\varepsilon_{T}^{B}\left(\lambda_{i}\right)\right]$ to have

$$
\Gamma_{L M}^{B}=\frac{\sqrt{N}\left[\overline{L M}_{N T}^{B}-E\left(£_{T}\right)\right]}{\sqrt{V\left(£_{T}\right)}}
$$

Im and Lee (2001) derive the asymptotic properties of $\Gamma_{L M}^{B}$ and show that it has a standard normal distribution. Indeed they show that the panel LM test statistic remains the same with or without a break. In fact, the distribution of the panel LM unit root test statistics is unaffected by break. The hypotheses tested in panel data can be described as follows:

Null Hypothesis : $\beta_{i}=0$ for all $\mathrm{i}$, Alternative Hypothesis : $\beta_{i}<0$ for at least one $\mathrm{i}$.

\section{Econometric Investigation and result interpretation}

The mixed results from unit root tests in previous research on PPP suggests that the question remains as to whether or not the theory is empirically valid. To perform our tests, we employ quarterly data on real exchange rates from nine Central and East European countries (Croatia, the Czech Republic, Estonia, Hungary, Latvia, Lithuania, Poland, Slovakia and Slovenia), covering the period from the first quarter of 1995 to the last quarter of 2000. All series are transformed into natural logarithms and all variables are in index form with the first quarter of 1995 as the base. The period prior to 1995 is eliminated from the analysis because, during the early years of the transition process, changes overall inflation, especially appreciation of the real exchange rate were dominated by firm-level restructuring involving massive lay-offs, the adjustment of distorted relative prices from the Communist era and pegged exchange rate regimes motivated by concerns for macroeconomic stabilization. Therefore, even if those earlier data appear to correspond to some of the model's predictions, the PPP did not drive price and real exchange rate movements during that turbulent period. 
In order to provide a robust analysis, we compare both univariate and panel LM unit root test results with and without structural break. We begin with the Schmidt and Phillips univariate LM unit root test without structural change. We then move to extensions that allow for one break, since our time series covers periods during which structural change may have occurred due to the important structural reforms implemented by those countries. In addition to the Schmidt and Phillips no-break test, we employ the univariate one and the Lee and Strazicich (1999a, 1999b) minimum LM unit root tests with one break to determine the structural break point in each country. After determining the optimal break point, we employ the panel LM unit root test of Im and Lee (2001). For comparison, we additionally show the panel LM test results with no breaks.

To determine the optimal break point in the panel LM test, we utilize the univariate .minimum.LM unit root tests of Lee and Strazicich (1999a, 1999b). These test are comparable to the corresponding Dickey and Fuller type endogenous break tests of Zivot and Andrews (1992). The performance of the LM test is comparable to or superior to these counter-part tests in terms of size and power. In addition, the LM unit root tests are not subject to spurious rejections under the null. In each test, the break point is determined endogenously from the data via a grid-search by selecting the break where the unit root test statistic is minimum. Using the minimum LM tests of Lee and Strazicich (1999a, 1999b), the unit root test statistic is estimated at each of one break point. The procedure is repeated over the time interval [.1T,.9T], to eliminate end points, until the break is determined where the unit root t-test statistic is minimized. The optimal number of lags in each country is determined by sequentially examining the t-statistic for the last lag coefficient to see if it is significant at the approximate $10 \%$ level in an asymptotic normal distribution. We begin with the one break LM test. If less than one break is significant, we employ the no-break LM unit root test. The corresponding LM unit root test statistic is then chosen after determining the optimal break point. After determining the appropriate unit root test statistic for each country, the panel LM test statistic is then calculated.

The results of testing are shown in table 1 in appendix. For the univariate LM test with no break, the unit root null can be rejected in four cases out eight (Croatia, Hungary, Poland, Slovakia) at the usual significance levels ${ }^{3}$. After allowing for structural break, the univariate minimum LM test rejects the unit root null for the nine eight countries at $5 \%$. So when allowing for structural

\footnotetext{
${ }^{3}$ Note that as we implement a one sided test a calculated statistic smaller than the critical value leads to the rejection of the null of a unit-root. At $5 \%$ for instance the critical value is -1.65 .
} 
breaks the univariate unit root tests are able to reject the null in all cases. Examination of the estimated break point reveals that structural breaks in real exchange rate are significant only in four countries out of nine (Croatia, Estonia, Hungary and Latvia).

Without allowing for structural breaks, the panel LM test statistic of 0.493 clearly indicates that the unit root null cannot be rejected due to increased power from panel data. This highlights the importance of allowing for structural change, even in the panel setting. On the contrary, after allowing for structural breaks, the panel test statistic of -5.95 strongly rejects the unit root null at less than $1 \%$. These results clearly demonstrate the gain in power from combining structural breaks with panel data. Since the panel LM test statistic is calculated using the average test statistic of all countries, it is possible that the panel results are due to a small number of outliers having a relatively large impact. Examination of the univariate test statistic (with breaks) for each country reveals that the totality of countries reject the unit root null at 5\%. We can, therefore, be confident that the panel test results are not due to outliers. These results demonstrate that the failure to reject the null in univariate tests is due to insufficient power. After combining structural breaks with panel data, the null hypothesis of unit root is clearly rejected. Overall, our finding support the convergence process and suggest that overwhelming majority of shocks to real exchange rate are temporary.

\section{Conclusion}

This paper has re-examined the empirical validity of PPP using quarterly data for 9 CEE countries for the period 1995:1200:4. We employed a variety of unit root tests, including the recently developed panel LM unit root test of Im and Lee (2001) that allows for heterogeneous structural change. By combining the use of structural breaks and panel data, our tests realized a significant gain in power as compared to previous empirical research. The choice of a unit-root test with breaks explains itself as well by the fact as these countries are in phase of transition and hence subject to several structural shocks. Contrary to univariate tests and/or those that ignore structural break, by combining panel data with structural break the PPP is strongly confirmed, which means the existence of a convergence process of prices between these countries and Europe. 


\section{References}

[1] Frankel, J.,and A. Rose, “A Panel Project on Purchasing Power Parity: Mean reversion within and between countries,” Journal of International Economics, Vol. 40: 209-224, 1996

[2] Froot, K. A., and K. Rogoff (1995), "Perspectives on PPP and long-run real exchange rates", in Grossman, G., and K. Rogoff (eds.) (1995), Handbook of International Economics, Volume 3. Amsterdam: North-Holland, 1647-1688.

[3] Hamilton, J. D. (1989), “A new approach to the economic analysis of nonstationary time series and the business cycle”, Econometrica 57, 357.384.

[4] Im, K.S., M.H. Pesaran, and Y. Shin (1997), “Testing for unit roots in heterogeneous panels”, Discussion Paper, University of Cambridge, June.

[5] Im, K.S., M.H. Pesaran, and Y. Shin (2003), “Testing for Unit Roots in Heterogeneous Panels”, Journal of Econometrics, 115: 53-74.

[6] Im, K. S., and J. Lee (2001), "Panel LM Unit Root Test with Level Shits", Discussion paper, Department of Economics, University of Central Florida.

[7] Kao, C. (1999), "Spurious Regression and Residual-Based Tests for Cointegration in Panel Data”, Journal of Econometrics, 90: 1-44.

[8] Lee, J., and M. Strazicich (2001), "Testing the Null of Stationarity in the Presence of One Structural Break”, Applied Economics Letters, 8, 377-382.

[9] Levin A., and C.F. Lin (1993), "Unit root tests in panel data, asymptotic and finite sample properties”, U.C. San Diego Working paper.

[10] Levin, A., C.F. Lin, and C.J. Chu (2002), Unit Root Tests in Panel Data: Asymptotic and Finite-Sample Properties, Journal of Econometrics, 108, 1-24.

[11] Lumsdaine, R. L. and D. H. Papell (1997), "Multiple trend breaks and the unit-root hypothesis”, The Review of Economics and Statistics, 212.218.

[12] McCoskey, S., and C. Kao (1999), "Testing the Stability of a Production Function with Urbanization as a Shift Factor”, Oxford Bulletin of Economics and Statistics, Special issue, 671-690.

[13] Maddala, G. and Wu, S. (1999), "A comparative study of unit root tests and a new simple test”, Oxford Bulletin of Economics and Statistics 61, 631-652.

[14] O’Connel (1998), “The Overvaluation of Purchasing Power Parity,” Journal of International Economics, Vol. 44, pp 1-19. 
[15] Pedroni P. (1999), “Critical values for cointegrating tests in heterogeneous panels with multiple regressors”, Oxford Bulletin of Economics and Statistics, Vol 61, Supplement, pp 653-670.

[16] Pedroni P. (2000) "Fully Modified OLS for Heterogeneous Cointegrated Panels,” in Advances in Econometrics, Vol. 15, p 93-130.

[17] Pedroni, P. (2004), Panel Cointegration; Asymptotic and Finite Sample Properties of Pooled Time Series Tests with an Application to the Purchasing Power Parity Hypothesis, Econometric Theory, 20, 597-625.

[18] Sarno L., and Taylor M.P (2002), “The Economics of Exchange Rates”, Cambridge University Press.

[19] Zivot, E., and D. W. K. Andrews (1992): "Further Evidence on the Great Crash, the Oil Price Shock, and the Unit-Root Hypothesis”, Journal of Business \& Economic Statistics, (10, 3), 251-270. 


\section{Appendix}

Table 1: Panel-LM Unit Root tests

\begin{tabular}{|c|c|c|c|c|c|}
\hline Country & $\begin{array}{c}\text { Individual } \\
\text { LM-statistic } \\
\text { without break }\end{array}$ & Lags & $\begin{array}{c}\text { Individual } \\
\text { LM-statistic } \\
\text { with breaks }\end{array}$ & Lags & $\begin{array}{c}\text { Optimal break } \\
\text { point }\end{array}$ \\
\hline Croatia & -2.177 & 0 & -4.531 & 2 & 14 \\
\hline Hungary & -3.125 & 1 & -1.726 & 0 & 17 \\
\hline The Czech & -1.533 & 0 & -2.576 & 0 & \\
\hline \multicolumn{6}{|l|}{ Republic } \\
\hline Slovakia & -2.454 & 1 & -4.488 & 1 & \\
\hline Slovenia & -1.209 & 3 & -3.923 & 4 & \\
\hline Estonia & -1.116 & 3 & -2.291 & 2 & 9 \\
\hline Latvia & -1.455 & 0 & -3.529 & 4 & 13 \\
\hline Lithuania & -1.303 & 0 & -3.096 & 1 & \\
\hline Poland & -2.007 & 0 & -4.235 & 1 & \\
\hline Panel LM-stat & 0.493 & & -5.953 & & \\
\hline
\end{tabular}

Note that as this is a one sided test a calculated statistic smaller than the critical value (from the normal distribution) leads to the rejection of the null of a unit-root. At 5\% for instance this critical value is -1.65 .

Note that the real exchange rate (quoted to incertain) is calculated as the ratio of the Consumer Price Indices (CPI) and that the German mark is taken as a benchmark. 


\section{DAVIDSON INSTITUTE WORKING PAPER SERIES - Most Recent Papers}

The entire Working Paper Series may be downloaded free of charge at: www.wdi.bus.umich.edu

CURRENT AS OF 4/29/05

\begin{tabular}{|c|c|c|}
\hline Publication & Authors & Date \\
\hline $\begin{array}{l}\text { No. 768: Testing for inflation convergence between the Euro Zone } \\
\text { and its CEE partners }\end{array}$ & Imed Drine and Christophe Rault & Apr. 2005 \\
\hline $\begin{array}{l}\text { No. 767: Labor Mobility during Transition: Evidence from the Czech } \\
\text { Republic }\end{array}$ & Jan Fidrmuc & Apr. 2005 \\
\hline $\begin{array}{l}\text { No. 766: Formation of social capital in Central and Eastern Europe: } \\
\text { Understanding the gap vis-à-vis developed countries }\end{array}$ & Jan Fidrmuc and Klarita Gërxhani & Apr. 2005 \\
\hline $\begin{array}{l}\text { No. 765: Do Regional Integration Agreements Increase Business-Cycle } \\
\text { Convergence? Evidence From APEC and NAFTA }\end{array}$ & $\begin{array}{l}\text { Viviana Fernandez and Ali M. } \\
\text { Kutan }\end{array}$ & Apr. 2005 \\
\hline $\begin{array}{l}\text { No. 764: State Regulations, Job Search and Wage Bargaining: A Study } \\
\text { in the Economics of the Informal Sector }\end{array}$ & Maxim Bouev & Apr. 2005 \\
\hline $\begin{array}{l}\text { No. 763: The Feldstein-Horioka Puzzle Revisited: An “European- } \\
\text { Regional” Perspective }\end{array}$ & $\begin{array}{l}\text { Jérôme Hericourt and Mathilde } \\
\text { Maurel }\end{array}$ & Apr. 2005 \\
\hline $\begin{array}{l}\text { No. 762: Transatlantic Differences in Labour Markets Changes in Wage } \\
\text { and Non-Employment Structures in the 1980s and the 1990s }\end{array}$ & Patrick A. Puhani & Mar. 2005 \\
\hline $\begin{array}{l}\text { No. 761: Resolution, Recovery and Survival: The Evolution of Payment } \\
\text { Disputes in Post-Socialist Europe }\end{array}$ & Willi & Mar. 2005 \\
\hline $\begin{array}{l}\text { No. 760: Official Foreign Exchange Interventions in the Czech } \\
\text { Republic: Did They Matter? }\end{array}$ & Balázs Ége & Mar. 2005 \\
\hline $\begin{array}{l}\text { No. 759: Assessing Market Expectations on Exchange Rates and } \\
\text { Inflation: A Pilot Forecasting System for Bulgaria }\end{array}$ & $\begin{array}{l}\text { Michael Berlemann, Kalina } \\
\text { Dimitrova, \& Nikolay Nenovsky }\end{array}$ & Mar. 2005 \\
\hline No. 758: Attitudes and Performance: An Analysis of Russian Workers & $\begin{array}{l}\text { Susan J. Linz and Anastasia } \\
\text { Semykina }\end{array}$ & Mar. 2005 \\
\hline $\begin{array}{l}\text { No. 757: Barter, Credit, and Welfare: A theoretical inquiry into the } \\
\text { barter phenomenon in Russia }\end{array}$ & José Noguera and Susan J. Linz & Mar. 2005 \\
\hline $\begin{array}{l}\text { No. 756: Sorting, Selection, and Transformation of the Return to } \\
\text { College Education In China }\end{array}$ & $\begin{array}{l}\text { Belton M. Fleisher, Haizheng Li, } \\
\text { Shi Li, and Xiaojun Wang }\end{array}$ & Mar. 2005 \\
\hline $\begin{array}{l}\text { No. 755: Foreign Exchange Interventions in Emerging Europe: } \\
\text { Should We Give a Damn? The Case of Croatia and Turkey }\end{array}$ & Balázs Égert and Maroje Lang & Mar. 2005 \\
\hline $\begin{array}{l}\text { No. 754: Targeting Relative Inflation Forecast as Monetary Policy } \\
\text { Framework for Adopting Euro }\end{array}$ & T. Orlowski & Feb. 2005 \\
\hline $\begin{array}{l}\text { No. 753: Internet Entrepreneurship: Networks and Performance of } \\
\text { Internet Ventures In China }\end{array}$ & Bat Batjargal & Feb. 2005 \\
\hline $\begin{array}{l}\text { No. 752: Network Triads: Transitivity, Referral and Venture Capital } \\
\text { Decisions in China and Russia }\end{array}$ & Bat Batjargal & Feb. 2005 \\
\hline $\begin{array}{l}\text { No. 751: Software Entrepreneurship: Knowledge Networks and } \\
\text { Performance Of Software Ventures In China and Russia }\end{array}$ & Bat Batjargal & Feb. 2005 \\
\hline $\begin{array}{l}\text { No. 750: Retained State Shareholding in Chinese PLCs: Does } \\
\text { Government Ownership Reduce Corporate Value? }\end{array}$ & Lihui Tian and Saul Estrin & Feb. 2005 \\
\hline No. 749: Financial Development and Technology & Solomon Tadesse & Feb. 2005 \\
\hline No. 748: Banking Fragility and Disclosure: International Evidence & Solomon Tadesse & Feb. 2005 \\
\hline $\begin{array}{l}\text { No. 747: Consolidation, Scale Economies and Technological Change in } \\
\text { Japanese Banking }\end{array}$ & Solomon Tadesse & Feb. 2005 \\
\hline $\begin{array}{l}\text { No. 746: Trade Creation and Diversion Effects of Europe’s Regional } \\
\text { Liberalization Agreements }\end{array}$ & Yener Kandogan & Feb. 2005 \\
\hline No. 745: Quality of Institutions, Credit Markets and Bankruptcy & Christa Hainz & Feb. 2005 \\
\hline $\begin{array}{l}\text { No. 744: How Transition Paths Differ: Enterprise Performance in Russia } \\
\text { and China }\end{array}$ & Sumon Bhaumik and Saul Estrin & Jan. 2005 \\
\hline $\begin{array}{l}\text { No. 743: Inflation Targeting, Between Rhetoric and Reality. The Case } \\
\text { of Transition Economies }\end{array}$ & Daniel Daianu and Laurian Lungu & Jan. 2005 \\
\hline $\begin{array}{l}\text { No. 742: How Does Law Affect Finance? An Empirical Examination of } \\
\text { Tunneling in an Emerging Market }\end{array}$ & $\begin{array}{l}\text { Vladimir Atanasov, Conrad S. } \\
\text { Ciccotello, \& Stanley B. Gyoshev }\end{array}$ & Jan. 2005 \\
\hline $\begin{array}{l}\text { No. 741: Do Insider Trading Laws Matter? Some Preliminary } \\
\text { Comparative Evidence }\end{array}$ & Laura Nyantung Beny & Jan. 2005 \\
\hline
\end{tabular}

